\title{
Pesticide Toxicity Profile: Chlorinated Hydrocarbon Pesticides ${ }^{1}$
}

Frederick M. Fishel ${ }^{2}$

This document provides a general overview of human toxicity, provides a listing of laboratory animal and wildife toxicities and a cross reference of chemical and common names with their trade names of the chlorinated hydrocarbon pesticides registered for use in Florida.

\section{General}

Chlorinated Hydrocarbons are a group of chemicals composed of carbon, chlorine and hydrogen. As pesticides, they are also referred to by several other names, including chlorinated organics, chlorinated insecticides and chlorinated synthetics. Although the first chlorinated hydrocarbon was synthesized in 1874, its insecticidal properties were not discovered until 1939 by the Swiss chemist, Paul Müller. It was introduced as DDT in 1942 during World War II and its subsequent use is responsible for saving millions of lives from vectored diseases such as typhus and malaria. The advantages of these synthetic chemicals over previously used botanical or natural insecticides were improved efficacy, lower use rates, lower costs and greater persistence. As with most of the chlorinated hydrocarbons, DDT has been banned for use in the United States, but is still used in some developing countries for combating insect vectors of disease. Other members of this chemical group no longer in use in the United States include aldrin, dieldrin, heptachlor, mirex, chlordecone, and chlordane. Others remaining registered are active ingredients of various home and garden products and some agricultural, structural, and environmental pest control products. One particular subgroup of these chemicals, known as cylcodienes, were especially persistent, which made them useful for controlling structural pests such as termites. Their persistence is attributed to their long soil-life and stability in the presence of the untraviolet radiation from sunlight. Many structures treated with one of these compounds are still protected today. One cylcodiene still registered for use, endosulfan, is less persistent. The Environmental Protection Agency determined that the potential for environmental contamination from the persistent members of this group of chemicals was sufficient to issue a ban on their use.

1. This document is PI-53, one of a series of the Pesticide Information Office, Florida Cooperative Extension Service, Institute of Food and Agricultural Sciences, University of Florida. Original publication date July 2005. Visit the EDIS Web Site at http://edis.ifas.ufl.edu.

2. Frederick M. Fishel, Associate Professor, Agronomy Department, and Director, Pesticide Information Office; Florida Cooperative Extension Service, Institute of Food and Agricultural Sciences, University of Florida, Gainesville, FL 32611.

The use of trade names in this publication is solely for the purpose of providing specific information. UF/IFAS does not guarantee or warranty the products named, and references to them in this publication does not signify our approval to the exclusion of other products of suitable composition. Use pesticides safely. Read and follow directions on the manufacturer's label.

The Institute of Food and Agricultural Sciences (IFAS) is an Equal Opportunity Institution authorized to provide research, educational information and other services only to individuals and institutions that function with non-discrimination with respect to race, creed, color, religion, age, disability, sex, sexual orientation, marital status, national origin, political opinions or affiliations. U.S. Department of Agriculture, Cooperative Extension Service, University of Florida, IFAS, Florida A. \& M. University Cooperative Extension Program, and Boards of County Commissioners Cooperating. Larry Arrington, Dean 


\section{Toxicity}

The chlorinated hydrocarbons are all contact poisons, although they penetrate insect cuticle at differing rates. Because they are insoluble in water, they are not translocated within plants. They show a high affinity for fats, and are concentrated in fatty tissues of animals. In varying degrees, chlorinated hydrocarbons are absorbed from the gut and also by the lung and skin. The efficiency of dermal absorption is variable. Endosulfan is efficiently absorbed across the skin, while docofol is not. Lindane is absorbed even more efficiently across abraded skin, which becomes important when taking into account its use on children with severe dermatitis associated with scabies. The chief acute toxic action of the chlorinated hydrocarbons is on the nervous system. Acute symptoms of neurologic toxicity include tremor and involuntary muscular movement, which is due to the prolonged recovery phase of the affected neuron. There has been interest in the interaction of chlorinated hydrocarbons with endocrine receptors, particularly estrogen and androgen receptors. Some experimentation has shown that the function of the endocrine system may be altered by these interactions (Vonier, et al., 1996 and Fry, 1995). This in turn may alter the reproductive development and success of animals and humans. In addition, some chlorinated hydrocarbons may inhibit lactation and may also be developmental toxicants (Rogan, 1996). Besides environmental persistence, evidence of carcinogenic potential of some chlorinated hydrocarbons added more evidence for the Environmental Protection Agency to ban or restrict their uses. Mammalian toxicities for chlorinated hydrocarbon pesticides are shown in Table 1 . Table 2 lists the toxicities to wildlife by the common name of the chlorinated hydrocarbon pesticide. Table 3 provides a cross listing of many of the trade names that these products are registered and sold by in Florida.

\section{Additional Information}

Crop Protection Handbook. 2005. vol. 91. Willoughby, Ohio: Meister Publishing Co. http://www.meisterpro.com/mpn.
Fry, D.M. 1995. Reproductive effects in birds exposed to pesticides and industrial chemicals. Environ Health Perspect; 103 (Suppl. 7):165-171.

Nesheim, O.N, F.M. Fishel and M.A. Mossler. 2005. Toxicity of pesticides. UF/IFAS EDIS Document PI-13. http://edis.ifas.ufl.edu/PI008.

Reigart, J.R. and J.R. Roberts. 1999. Recognition and management of pesticide poisonings, $5^{\text {th }}$ edition. United States Environmental Protection Agency Publication EPA-735-R-98-003.

Rogan, W.J. 1996. Pollutants in breast milk. Arch Pediatr Adolesc Med; 150:981-990.

Seyler, L.A., et.al. 1994. Extension toxicology network (EXTOXNET). Cornell University and Michigan State University. http://extoxnet.orst.edu/index.html. Visited July 2005.

Vonier, P.M., D.A. Crain and J.A. McLachlan, et.al. 1996. Interaction of environmental chemicals with the estrogen and progesterone receptors from the oviduct of the American alligator. Environ Health Perspect; 104(12):1318-1322. 
Table 1. Chlorinated hydrocarbon pesticide mammalian toxicities ( $\mathrm{mg} / \mathrm{kg}$ of body weight).

\begin{tabular}{|l|c|c||}
\hline \hline Common name & Rat oral LD & Rabbit dermal LD $_{\text {50 }}$ \\
\hline Dicofol & $570-595$ & $>2,000$ \\
\hline Endosulfan & $18-220$ & $200-359$ \\
\hline Lindane & $88-270$ & 1,000 (rat) \\
\hline \hline
\end{tabular}

Table 2. Chlorinated hydrocarbon pesticide wildlife toxicity ranges.

\begin{tabular}{|c|c|c|c|}
\hline Common name & Bird acute oral LD ${ }_{50}(\mathrm{mg} / \mathrm{kg})^{*}$ & Fish (ppm) $)^{\star \star}$ & $\mathrm{Bee}^{\dagger}$ \\
\hline Dicofol & --- & $\mathrm{HT}$ & PNT \\
\hline Endosulfan & $33-243$ & VHT & MT \\
\hline Lindane & $>5,000$ & VHT & HT \\
\hline \multicolumn{4}{|c|}{ 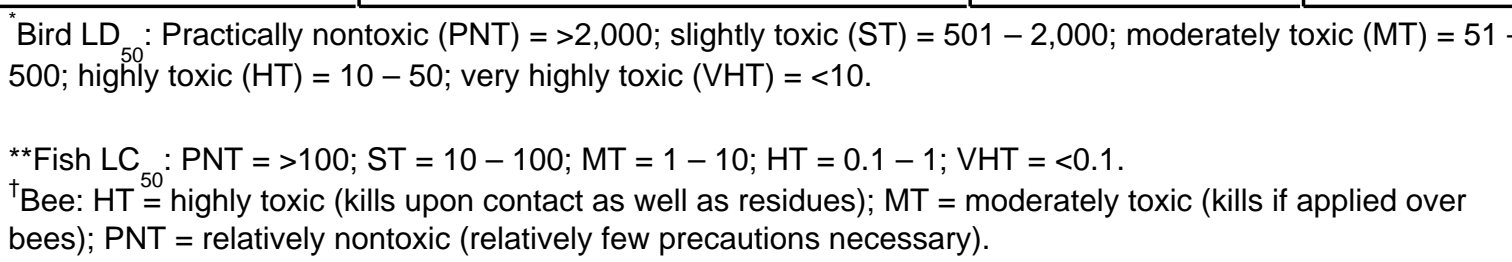 } \\
\hline
\end{tabular}

Table 3. Cross reference list of common, trade and chemical names of chlorinated hydrocarbon pesticides.

\begin{tabular}{|c|c|c|}
\hline Common name & Trade names* & Chemical name \\
\hline Dicofol & Kelthane® & 4,4'-dichloro-alpha-(trichloromethyl)benzhydrol \\
\hline Endosulfan & Phaser®, Thiodan® & $\begin{array}{l}6,7,8,9,10,10 \text {-hexachloro-1,5,5a,6,9,9a- } \\
\text { hexahydro-6,9-methano-2,4,3-benzodioxathiepin }\end{array}$ \\
\hline Lindane & Several agricultural products & $\begin{array}{l}\text { 1-alpha, 2-alpha, 3-beta, 4-alpha, 5-alpha, } \\
\text { 6-beta-hexachlorocyclohexane }\end{array}$ \\
\hline
\end{tabular}

